\title{
TRAINING OF HAND CRAFTS WITH SILICONE MOLD METHOD FOR THE PEOPLE OF MERUYA SELATAN
}

\author{
Silvi Ariyanti and M. Sobron Yamin Lubis \\ Universitas Mercu Buana Jakarta, Indonesia.
}

\begin{abstract}
Child-Friendly Integrated Public Space (RPTRA) is a place and/or open space that combines the activities and activities of citizens by implementing 10 (ten) Principal Empowerment and Family Welfare programs to integrate with the Child-Friendly Cities program. One of the goals of the establishment of the RPTRA is to improve the infrastructure and facilities for citizens' social activities including the development of the knowledge and skills of PKK cadres that work to increase family income. Therefore, the importance of this activity is to help the community in improving skills so as to be able to open business opportunities, especially in the manufacture of handicrafts with the Silicon Moulding method. So that this activity can take place and produce maximum benefits, we start by providing training on the application of science and technology, where the activity is to provide skills training on making handicrafts using the Silicon Moulding method. The target audience of the community service program activities that will be held are the ladies and youth cadets with a total of 15 people. The training activities are carried out in one (1) day, housed in the secretariat of the RPTRA of Meruya Selatan Village, Kembangan District, West Jakarta. The workshop activities will be held on February 8,2019 , starting at $08.00-12.30$ WIB. Overall the participants stated that the workshop was interesting, that many 'new' things were learned and learned during the activity. The training material is very useful in 'sending' participants to further enhance skills and open business opportunities.
\end{abstract}

Keywords: RPTRA, Silicon, Molding, Resins, and Business Opportunities.

\section{INTRODUCTION}

\section{Situation Analysis}

Child-Friendly Integrated Public Space (RPTRA) is a place and/or open space that combines the activities and activities of citizens by implementing 10 (ten) Principal Empowerment and Family Welfare programs to integrate with the Child-Friendly Cities program.

The DKI Provincial Government has previously inaugurated 9 RPTRAs, namely Sungai Bambu Utara, Gandaria Selatan, Cideng, Kembangan Utara, Cililitan, Untung Jawa Island, Sunter, Pulogebang Flats and Meruya Utara in phase II. It is planned that Ahok will also inaugurate the Phase II Karet Tengsin RPTRA on Jalan Karet Pasar Baru Barat I, Tanah Abang, Central Jakarta. Therefore the importance of carrying out community service activities is to assist the community in improving skills so as to be able to open business opportunities especially in the manufacture of handicrafts by using Silicon Molding souvenir methods based on resin materials.

The purpose of community service activities is to improve community skills in making creative products and increase the ability of the community to see business opportunities.

This community service is expected to contribute to the parties concerned, namely: for the RPTRA of Meruya Selatan Village, West Jakarta is to produce superior products which become the icon of Meruya Selatan Village in West Jakarta in the framework of productive business. The RPTRA of Meruya Selatan Village in West Jakarta can be a source of productive economic activities for the manager of the South Meruya Village RPTRA.

The contribution of this activity to Mercu Buana University Jakarta is as a means of implementing the research results of Mercu Buana University lecturers who contribute to community empowerment.

\section{TARGETS AND RESULT}

This activity is certainly not easy, where RPTRA residents have their respective activities in their daily lives so it is rather difficult to participate in this activity. However, the high motivation and enthusiasm of the participants to gain knowledge, so it is necessary to adjust the time for this activity to be carried out properly. For that to increase motivation and enthusiasm for entrepreneurship, it is necessary to have counselling and continuous encouragement so that activities can run and will be able to sustain their socioeconomic needs.

So that this activity can take place and produce maximum benefits, we start by providing training on the application of science and technology, where the activity is to provide skills training on the manufacture of souvenir products made from resin. As a first step taken is to choose the prototype form of the product to be 
made, then make a pattern from clay and make a mould made of silicon. Next, determine the combination of a mixture of resin and liquid catalyst that will be poured into the silicone mould. After pouring, the next step is to wait a few hours for the resin to dry to become solid and then remove the resin from the mold. The resulting solid resin is then finished to get a quality product so that it has commercial competitiveness. In this activity, the training consisted of the delivery of material by lecturers who also involved students. Then proceed with the practice of making patterns, making silicone moulds and resin setting which is carried out together with students and trainees.

\section{METHOD OF IMPLEMENTATION}

\section{Target}

The target audience for the community service program activities that will be held are the mothers with a total of 20 people, and members of Youth Organization (4 people). As for the instructors and resource persons in this activity were UMB lecturers who had competence in making handicrafts using the Silicon Molding method.

\section{Activity Method}

The method of activities that will be used in providing insight and transparent herbal soap production skills to the South Merua RPTRA Manager, PKK Women in Meruya Selatan Village, and Karang Taruna of Meruya Selatan Village in West Jakarta is as follows:

\section{Varied Lectures and Discussion Questions and Answers}

This method was chosen to convey concepts that are important to be understood and mastered by trainees. The use of this method with the consideration that the lecture method combined with audio and video can provide relatively much material in a compact, fast and easy.

\section{Demonstration}

This method was chosen to show a work process that is the stages of making Silicon Molding. The demonstration was carried out by the instructor in front of the participants then the participants were divided into four groups given the opportunity to make a prototype.

\section{RESULTS AND DISCUSSION Implementation of Activities}

The training activities are carried out in one (1) day, housed in the secretariat of the RPTRA of Meruya Selatan Village, Kembangan District, West Jakarta. The workshop will be held on February 10, 2019, starting at 08.00 12.30 WIB.

\section{Activities Materials and Equipment}

\section{Make One-Face Resin Molding With Silicone Rubber}

Fibreglass is a chemical product called resin, the reinforcing bone is called meth or glass fibre and as a hardener is usually added talc powder, from which all materials can be created or duplicate whatever objects. Such as tables, chairs, statues, game tools.dsb. To make or duplicate a complex object, we must first have the master. We can make this master from wood, resin, fibreglass, plastic, melamine, clay, and so on.

The first step is to make goods from fibreglass, we must make a reference or mould, first prepare the model, can be from ready-made items such as porcelain statues or plastic dolls but if you want to make your own work you can make wood or clay/clay material, you can also from toy wax material.

What needs to be prepared are resins, catalysts, silicone rubber, toy wax clays, reference strips (shoe polish or floor polish), wooden sun dips, plastic cups, small scales, measuring cups, glasses, scissors, cutters, duct tape, duster, large brushes, Small brush and glass (as a setting)

\section{Make One-Face Reference / Prints}

Flat the toy/clay candle on the glass table, place the model on top, give a perimeter fence around the model distance of $2 \mathrm{~cm}$. Apply the reference release from shoe polish/floor polish with a small brush to the entire model. Pour silicone rubber into $240 \mathrm{ml}$ plastic cups. Drops with a catalyst of 140 drops. Stir it evenly. Pour into the model, flatten with wooden sun dip. the rubber will freeze for about 2-3 hours. After the rubber has frozen, prepare a cast about $0.5 \mathrm{~kg}$, mix with water, squeeze by hand, not too thick or runny, then pour into the model evenly, the cast will harden for about 15 minutes. The model can be removed about 20 minutes later, remove the wax/clay fence, then the model has reversed clean all the wax, remove the model from the cast, and the rubber and then the rubber is put back in its original position into the cast. 


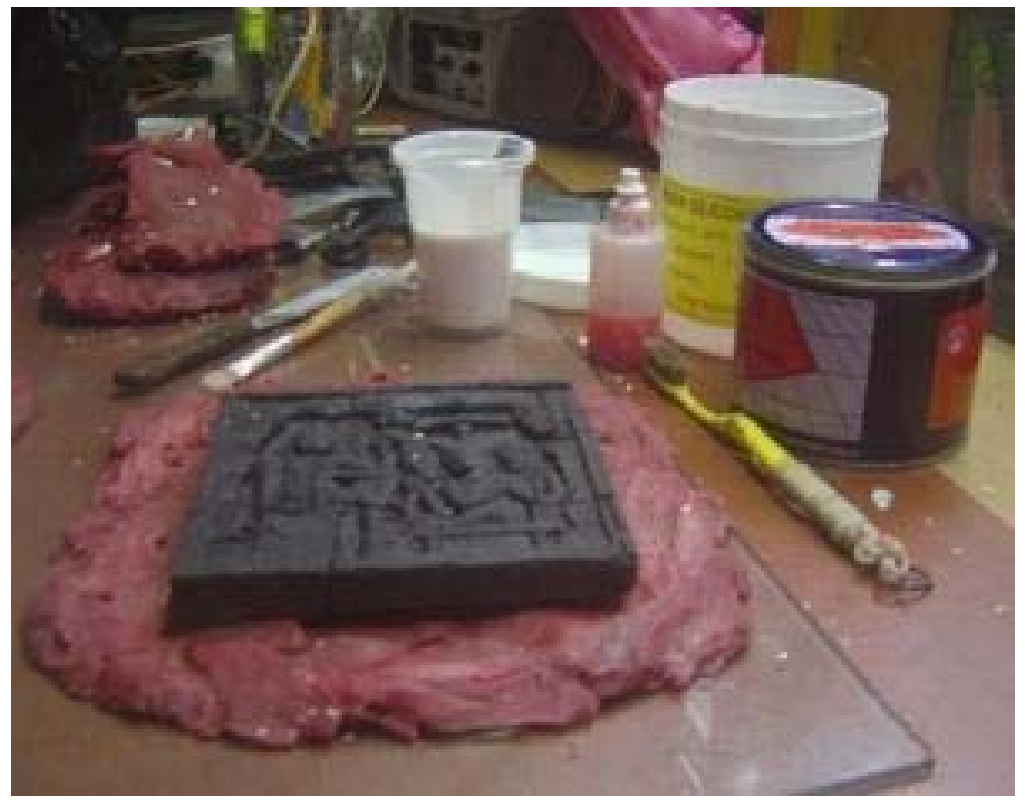

Figure 1 The model is placed on a clay plate

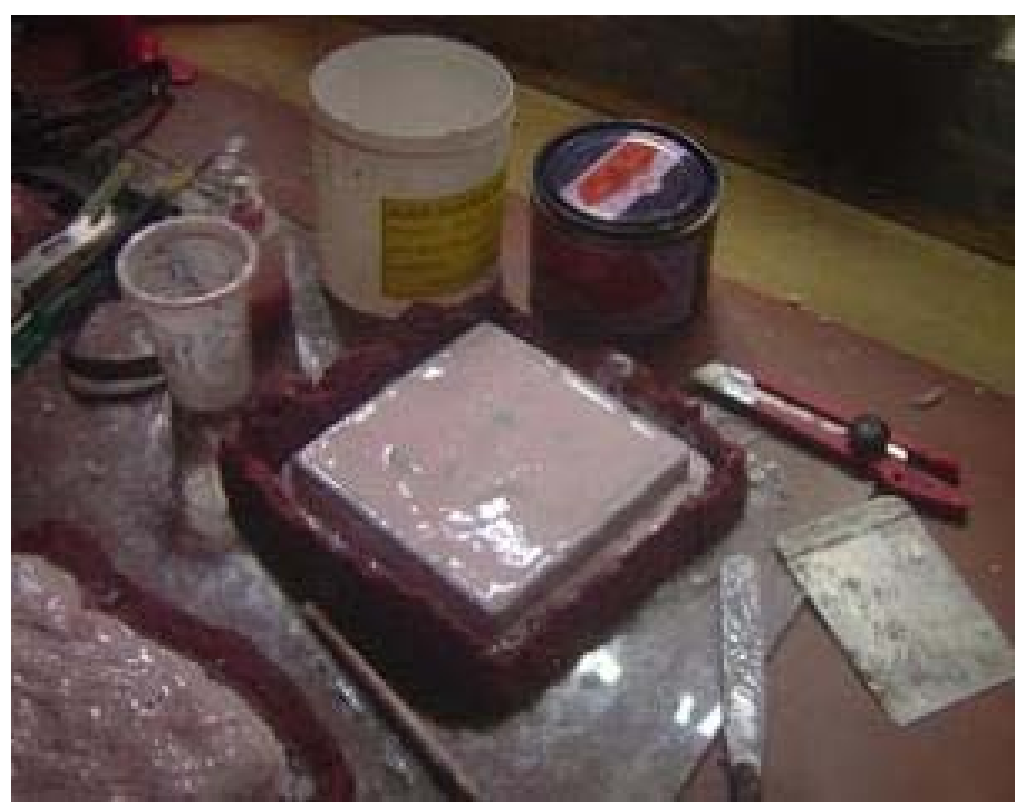

Figure 2 The edge of the model is given a wax fence

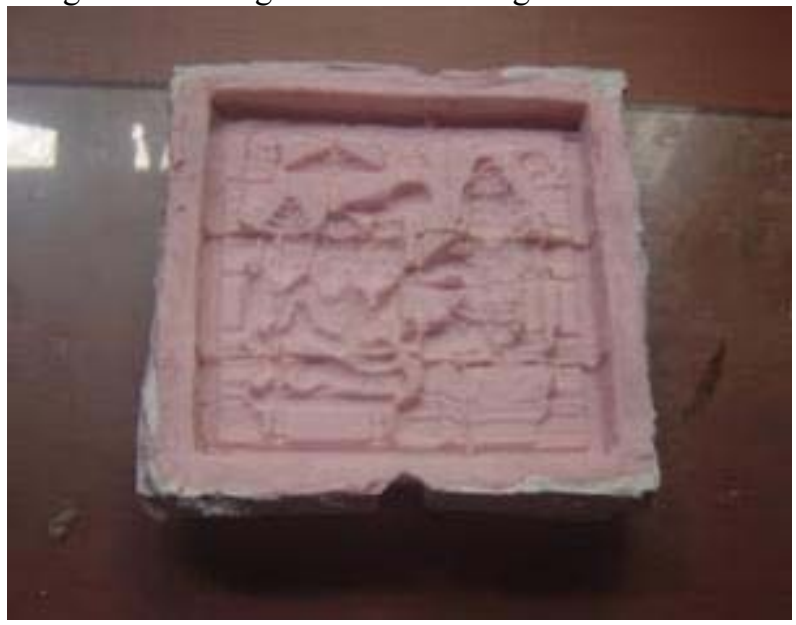

Figure 3 Silicones that start to harden 


\section{Print / Pour;}

First, rub the rubber with the reference release, if you want to see the printout, you can try it first with a cast. Pour the cast which has been dissolved with water into the mould. 15 minutes after hardening, remove from the mould. Print using fibre resin, prepare resin, catalyst, glass for size, talc, met / glass fibre, stirrer, wooden sun dip, cutter, scissors, plastic cup. Pour $1 / 2$ cup mixed resin with talk about 1 tablespoon, stir evenly, give about 20 drops of catalyst, stir a little to the reference, flatten with a brush over the entire surface of the rubber, after slightly thickening for the dough again, apply again then give tear the meth with the resin while pressing press using the brush again, tear the meth with the resin and press while smearing it with resin. For thickness, it depends on the need if the object is small enough 2-3 times the last coat is spread again with resin as a cover. The resin will harden for around 1-2 hours. After hard the mould can be removed from the reference, to trim the edges of the printed output, it can be cut or cut with a cutter. The final result can be painted.

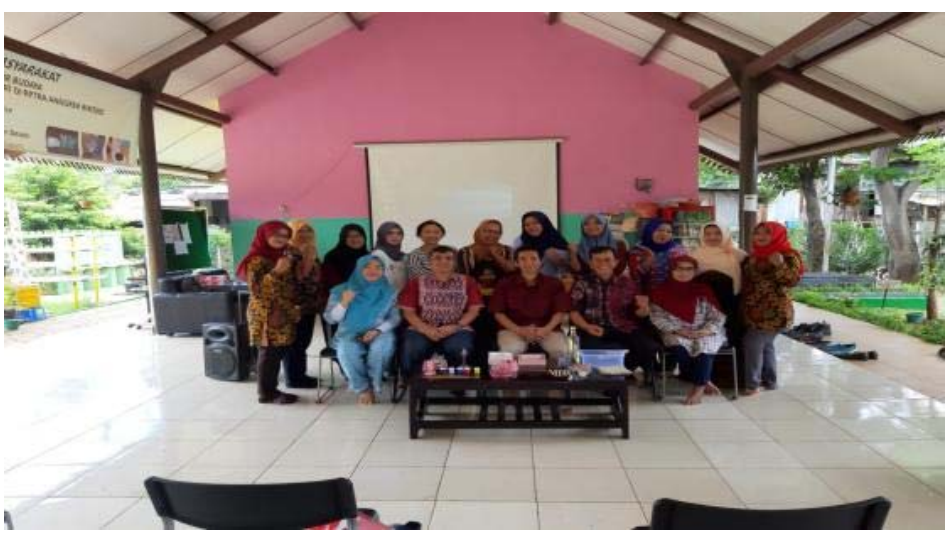

Figure 4 Training Participants and Team Instructors

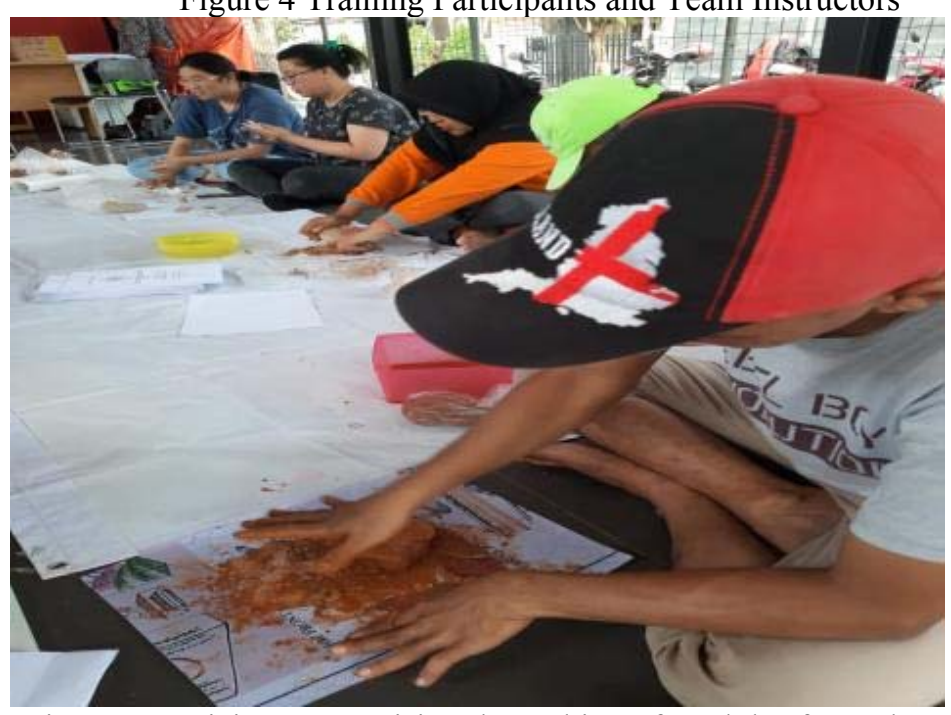

Figure 5 Participants practising the making of modules from clay

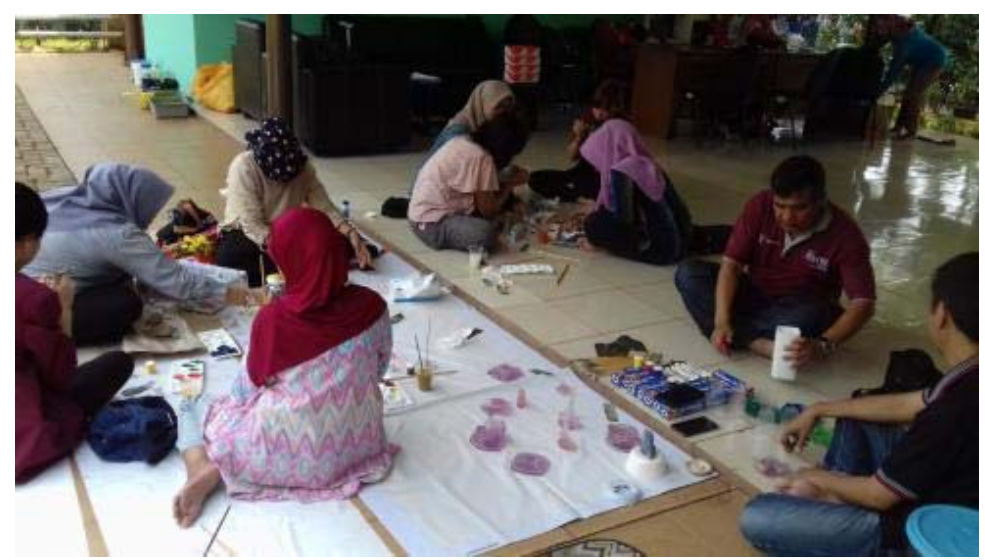

Figure 6 Making Silicone Molding 


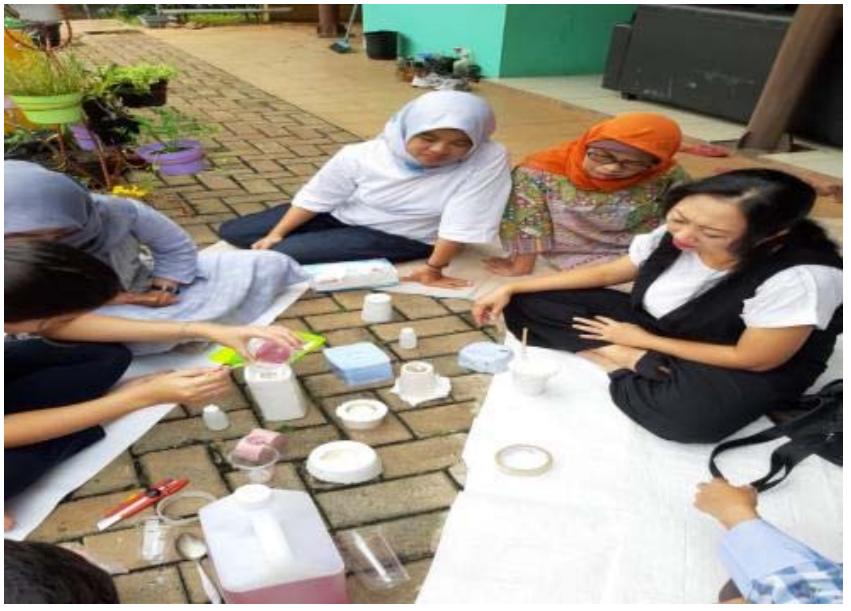

Figure 7: Casting Silicon Resin

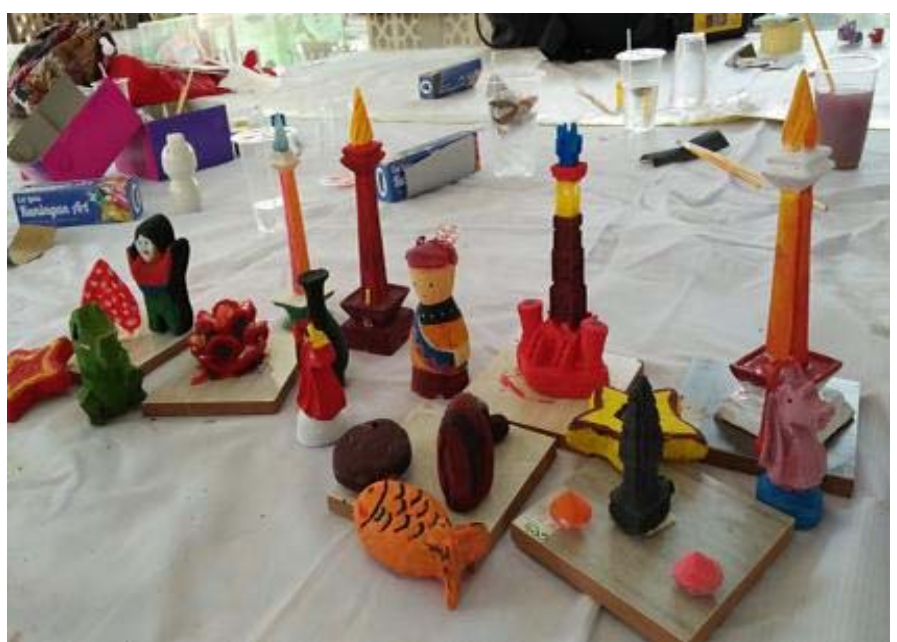

Results 8 Crafts made from resin with silicone moulds

\section{CONCLUSION}

Overall, workshop participants are dominated by individuals who have personalities with friends. Participants are able to make presentations using the silicon molding method with their own creations. The class atmosphere is quite lively and 'alive'. Participants are creative and tend to express their opinions openly, both in group discussions and individually. Overall the participants stated that the workshop was interesting, that many 'new' things were learned and learned during the activity. The training material is very useful in 'sending' participants to further enhance skills and open business opportuni

\section{REFERENCES}

Mackanzie, Dorothy, 1997, GREEN DESIGN, Design for the Environment, Laurent King Publishing, London

Amsted, B.H., F. Ostwaid, Phillip, L. Begeman, Myron, 1993. Teknologi Mekanik. Cetakan keempat, Jakarta: PT. Gelora Aksara Pratama

Tempelman, Erik, Shercliff, Hugh, Eyben, Bruno Ninaber van, 2014. Manufacturing and Design, USA: Elsevier Ltd.

Callister, William D., 2007. Material Science and Enginering: an Introduction. Asia: John Willey\&Sons Pte Ltd $\underline{\text { http://sinarkimia.com/tips-membuat-cetakan-dari-silicon-rubber/ }}$

http://keramik88.com/ceramic-mould/cara-membuat-cetakan-silikon.html 